\title{
National Disease Research Interchange
}

National Cancer Institute

\section{Source}

National Cancer Institute. National Disease Research Interchange. NCI Thesaurus. Code C126658.

A federally-funded non-profit organization that acts as a liaison between tissue and organ donors and the scientific community. 